\title{
Optimization of NPK Fertilizers for Higher Yield and Quality of Strawberry (Gragaria $x$ Ananassa Duch.) Fruits
}

\author{
Jayant Kumar Maurya, Jagendra Pratap Singh, Saurabh Tomar* and Rajeev Kumar
}

Department of Horticulture, Chandra Shekhar Azad University of Agriculture and Technology

Kanpur 208002 (U.P.) India

*Corresponding author

\author{
A B S T R A C T
}

A pot experiment on strawberry cv. 'Chandlar' conducted in a horticulture garden at Kanpur, Uttar Pradesh during winter season of 2014-15. The treatments consisted 8 levels

Keywords

Strawberry,

NPK fertilizers,

Fruiting, Fruit yield,

Fruit quality.

Article Info

Accepted:

19 July 2017

Available Online:

10 September 2017 of NPK fertilizers viz., $\mathrm{F}_{0^{-}}$control, $\mathrm{F}_{1}-\mathrm{N}_{50} \mathrm{P}_{30} \mathrm{~K}_{30}, \mathrm{~F}_{2}-\mathrm{N}_{100} \mathrm{P}_{60} \mathrm{~K}_{60}, \mathrm{~F}_{3}-\mathrm{N}_{150} \mathrm{P}_{80} \mathrm{~K}_{80}, \mathrm{~F}_{4}-$ $\mathrm{N}_{200} \mathrm{P}_{100} \mathrm{~K}_{100}, \mathrm{~F}_{5}-\mathrm{N}_{250} \mathrm{P}_{120} \mathrm{~K}_{120}, \mathrm{~F}_{6}-\mathrm{N}_{300} \mathrm{P}_{140} \mathrm{~K}_{140}$ and $\mathrm{F}_{7}-\mathrm{N}_{350} \mathrm{P}_{160} \mathrm{~K}_{160} \mathrm{~kg} / \mathrm{ha}$. Cutting produced through runners were transplanted on 21.11.2014 in pots which continued till end of March, 2015. The results revealed that NPK dose of $250 \mathrm{Kg} \mathrm{N}+120 \mathrm{Kg} \mathrm{P}_{2} \mathrm{O}_{5}+$ $120 \mathrm{Kg} \mathrm{K} 2 \mathrm{O} /$ ha was proved to be the optimum with highest values of flower/plant (18.66), fruits/plant $(13.93)$, fruit length $(4.02 \mathrm{~cm})$, fruit diameter $(2.92 \mathrm{~cm})$, fruit weight $(15.00$ gm), fruit yield per plant (208.88 gm) and quality parameter viz., TSS (10.41 \%), total sugar $(5.93 \%)$ and vitamin ' $C$ ' $(54.20 \mathrm{mg} / \mathrm{g})$ against their lowest values of 7.13 fruits/plant, $2.71 \mathrm{~cm}$ fruit length, $2.05 \mathrm{~cm}$ fruit diameter, $10 \mathrm{~g}$ fruit weight, $71.25 \mathrm{~g} / \mathrm{plant}$ fruit yield, $7.03 \%$ TSS, $4.86 \%$ total sugar and $49.75 \mathrm{mg} / \mathrm{g}$ vitamin ' $\mathrm{C}$ ' recorded in the control treatment of no NPK fertilizers. Fruit acidity was estimated lowest of $0.70 \%$ with $\mathrm{N}_{250} \mathrm{P}_{120} \mathrm{~K}_{120} \mathrm{~kg} / \mathrm{ha}$ against highest of $0.85 \%$ without NPK application. Thus, $\mathrm{N}_{250} \mathrm{P}_{120} \mathrm{~K}_{120}$ $\mathrm{kg} /$ ha NPK level was proved optimum for higher yield and quality of strawberry fruits in central Uttar Pradesh condition.

\section{Introduction}

The cultivated strawberry (Fragaria $x$ Ananassa Duch.) cultivation in India gained momentum in the late sixties in Himanchal Pradesh and now in Uttarakhand. It is also used to be grown in Srinagar (J. \& K.), hills of Darjeeling and in the tropical areas of Gurgaon (Haryana), Meerut, Muzaffarnagar and Saharanpur (U.P.), Jalandhar and Gurdaspur (Punjab), Pune and Mahabaleshwar (Maharashtra) and Bangalore (Karnataka). It is grown for its fruits which at ripe are bright red in colour with a soft melting flesh of sweetish flavor.
It is used as fresh fruit being rich in vitamin ' $\mathrm{C}$ ' and minerals, has relatively low content of soluble carbohydrates. Besides, it has a special demand by the food processing units for preparation of jam, ice-cream, syrup and for canning. Propagation of strawberry is done conventionally by runner and, in general distributed as either base rooted plants or plugs. For better plant growth and higher fruit yield, proper nutrition of plants is very important. It responds well to applied fertilizer nutrients. Considering the importance of this fruit, an experiment to 
optimize the dose of NPK fertilizers for higher yield of better quality fruits, was conducted at Kanpur condition of central Uttar Pradesh.

\section{Materials and Methods}

A pot experiment on strawberry was conducted in Horticulture Garden of C.S. Azad University of Agric. \& Tech., Kanpur during the winter season of 2014-15. The experiment consisted 8 treatments viz., $\mathrm{F}_{0}-$ control (no fertilizer), $\mathrm{F}_{1}-50 \mathrm{~kg} \mathrm{~N}+30 \mathrm{~kg}$ $\mathrm{P}_{2} \mathrm{O}_{5}+30 \mathrm{Kg} \mathrm{K} \mathrm{K}_{2} \mathrm{O}, \mathrm{F}_{2}-100 \mathrm{~kg} \mathrm{~N}+60 \mathrm{~kg}$ $\mathrm{P}_{2} \mathrm{O}_{5}+60 \mathrm{Kg} \mathrm{K} \mathrm{K}_{2} \mathrm{O}, \mathrm{F}_{3}-150 \mathrm{~kg} \mathrm{~N}+80 \mathrm{~kg}$ $\mathrm{P}_{2} \mathrm{O}_{5}+80 \mathrm{Kg} \mathrm{K} 2 \mathrm{O}, \mathrm{F}_{4}-200 \mathrm{~kg} \mathrm{~N}+100 \mathrm{~kg}$ $\mathrm{P}_{2} \mathrm{O}_{5}+100 \mathrm{Kg} \mathrm{K} 2 \mathrm{O}, \mathrm{F}_{5}-250 \mathrm{~kg} \mathrm{~N}+120 \mathrm{~kg}$ $\mathrm{P}_{2} \mathrm{O}_{5}+120 \mathrm{Kg} \mathrm{K} 2 \mathrm{O}, \mathrm{F}_{6}-300 \mathrm{~kg} \mathrm{~N}+140 \mathrm{~kg}$ $\mathrm{P}_{2} \mathrm{O}_{5}+140 \mathrm{Kg} \mathrm{K} 2 \mathrm{O}$ and $\mathrm{F}_{7}-350 \mathrm{~kg} \mathrm{~N}+160$ $\mathrm{kg} \mathrm{P}_{2} \mathrm{O}_{5}+160 \mathrm{Kg} \mathrm{K} 2 \mathrm{O} / \mathrm{ha}$, which were tested in Randomized Block Design replicated thrice. There were 24 treatment plots in all where each plot had five pots. Thus, 120 earthen pots of $30 \mathrm{~cm}$ diameter uniform size were used. All pots were washed, cleaned and properly numbered for treatment symbols, replications and plants. The soil used for filling the pots was sandy loam of average fertility. Pots were filled with well dried, cleaned and sieved soil and FYM in equal proportion. The dose of fertilizers per pot of different treatments was calculated on the basis of $30 \times 30 \mathrm{~cm}$ distance planting which accounts to 1,11,111 plants/ha. For supply of $\mathrm{N}, \mathrm{P}$ and $\mathrm{K}$, the fertilizers urea, single super phosphate and muriate of potash, respectively were used. After filling the pots, total required dose of urea, SSP and MOP as per treatment pot were applied in different pots and well mixed with soil and FYM mixture. Then the filled material in each pot was pressed properly to make it firm and leveled. After that cutting of strawberry cv. 'Chandlar' plants produced through runners and obtained from Dr. Y.S. Parmar University of Horticulture and Forestry Solan (H.P.) was transplanted keeping single plant per pot on $21^{\text {st }}$ November, 2014. Soon after transplanting, each pot was watered uniformly with the help of cane having a fine nozzle. Regular morning and evening irrigation was given for a week and after that subsequent irrigations were given at 3-4 days interval till January end at 2-3 days interval beyond January. Two days after transplanting, each pot surface was mulched with $6 \mathrm{~cm}$ thick layer of dry grass. Weeding and hoeing in each pot were done as per requirement. The observations on growth, yield attributes and yield were recorded on all 5 plants per treatment and replication. The quality parameters of fruit were estimated as per standard methods recommended for other plant fruits.

\section{Results and Discussion}

\section{Effect on plant growth}

Plant growth in forms of plant height, number of leaves/plant and number of runners/plant (Table 1) increased with increasing levels of fertilizers upto highest level of $350 \mathrm{~kg} \mathrm{~N}+160$ $\mathrm{kg} \mathrm{P}_{2} \mathrm{O}_{5}+160 \mathrm{Kg} \mathrm{K} \mathrm{K}_{2} \mathrm{O} / \mathrm{ha}$. At this level of fertilizer, plant height was recorded significantly highest of $16.06 \mathrm{~cm}$ followed by $300 \mathrm{~kg} \mathrm{~N}+140 \mathrm{~kg} \mathrm{P}_{2} \mathrm{O}_{5}+140 \mathrm{Kg} \mathrm{K} \mathrm{K}_{2} \mathrm{O} / \mathrm{ha}$ level, number of leaves were counted maximum of 16.32/plant which were found significantly at par with 15.47 leaves counted under $300 \mathrm{~kg} \mathrm{~N}+140 \mathrm{~kg} \mathrm{P}_{2} \mathrm{O}_{5}+140 \mathrm{Kg}$ $\mathrm{K}_{2} \mathrm{O} / \mathrm{ha}$, and recorded maximum of 3.20 runners/plant which also remained significantly at par with 2.80 runners counted under $300 \mathrm{~kg} \mathrm{~N}+140 \mathrm{~kg} \mathrm{P}_{2} \mathrm{O}_{5}+140 \mathrm{Kg}$ $\mathrm{K}_{2} \mathrm{O} /$ ha. The highest figures of $16.06 \mathrm{~cm}$ plant height, $\quad 16.32$ leaves/plant and 3.20 runners/plant under highest fertilizers level were found 101.3, 83.4 and $109.2 \%$ higher over control (no fertilizer) and 15.0, 5.5 and $14.3 \%$ higher over next best fertility level of $300 \mathrm{~kg} \mathrm{~N}+140 \mathrm{~kg}_{2} \mathrm{O}_{5}+140 \mathrm{Kg} \mathrm{K} \mathrm{K}_{2} \mathrm{O} / \mathrm{ha}$, 
respectively. Increase in plant growth with increasing fertilizer levels might be attributed to better nutrition of plants where $\mathrm{N}, \mathrm{P}$ and $\mathrm{K}$ nutrient played their roles in improvement of plant growth. These results are in accordance with the findings of Gutal et al., (2005).

\section{Effect on flowering}

Flower initiation delayed with increasing fertilizer levels significantly up to $300 \mathrm{~kg} \mathrm{~N}+$ $140 \mathrm{~kg} \mathrm{P}_{2} \mathrm{O}_{5}+140 \mathrm{Kg} \mathrm{K} \mathrm{K}_{2} \mathrm{O} / \mathrm{ha}$ level which showed 13.13 days delay in flower initiation than control and 4.06 days delay than $250 \mathrm{~kg}$ $\mathrm{N}+120 \mathrm{~kg} \mathrm{P}_{2} \mathrm{O}_{5}+120 \mathrm{Kg} \mathrm{K} \mathrm{K}_{2} \mathrm{O} /$ ha level. Similarly flowering duration delayed significantly with up to $250 \mathrm{~kg} \mathrm{~N}+120 \mathrm{~kg}$ $\mathrm{P}_{2} \mathrm{O}_{5}+120 \mathrm{Kg} \mathrm{K} 2 \mathrm{O} /$ ha by the margin of 19.83 days over control. Delay in flowering with increasing fertilizer levels might be due to increase in vegetative growth which took more time to complete vegetative phase because of more utilization of nitrogen at higher rates of application.

Number of flowers/plant was recorded maximum of 18.66 under $F_{5}$ fertility of $250 \mathrm{~kg}$ $\mathrm{N}+120 \mathrm{~kg} \mathrm{P}_{2} \mathrm{O}_{5}+120 \mathrm{Kg} \mathrm{K}_{2} \mathrm{O} /$ ha which was found significantly at par with 17.06, 16.93 and 16.20 flowers/plant under $F_{3}, F_{6}$ and $F_{4}$ fertility, respectively but significantly higher than all other treatments. Thus $\mathrm{F}_{5}$ level of fertility produced $28.7 \%$ more flowers than $\mathrm{F}_{0}$ control and $9.4 \%$ more than next best fertility of $\mathrm{F}_{3}$.

\section{Effect on yield attributes and yield}

The yield attributes viz., number of fruits/plant, fruit length, fruit diameter and weight per fruit (Table 1) increased with increasing levels of fertilizers upto $\mathrm{F}_{5}$ of $250 \mathrm{~kg} \mathrm{~N}+120 \mathrm{~kg}_{2} \mathrm{O}_{5}+120 \mathrm{Kg} \mathrm{K} \mathrm{K}_{2} \mathrm{O} / \mathrm{ha}$ beyond which significantly reduction was observed at $\mathrm{F}_{7}$ level of fertilizers in all cases. The fertilizers level $\mathrm{F}_{5}$ of $250 \mathrm{~kg} \mathrm{~N}+120 \mathrm{~kg}$ $\mathrm{P}_{2} \mathrm{O}_{5}+120 \mathrm{Kg} \mathrm{K}_{2} \mathrm{O} / \mathrm{ha}$ recorded highest values of 13.93 fruits per plant, $4.02 \mathrm{~cm}$ fruit length, $2.92 \mathrm{~cm}$ fruit diameter and $15 \mathrm{~g}$ fruit weight. These values were found 95.4, 48.3, 42.4 and $50.0 \%$ higher over control $\left(\mathrm{F}_{0}\right)$ and 7.2, 1.0, 9.0 and $11.4 \%$ higher over next best treatment $\mathrm{F}_{6}$, respectively. These results show that fertilizers had maximum positive effect on number of fruits/plant followed by on fruit weight. Higher number of fruits/plant might be attributed to more number of flowers/plant and their successful pollination and fertilization while fruit weight seems to be attributed to fruit length and diameter because of proper plant nutrition under optimum application of balanced $\mathrm{N}, \mathrm{P}$ and $\mathrm{K}$ nutrients in F5 treatment of $250 \mathrm{~kg} \mathrm{~N}+120 \mathrm{~kg} \mathrm{P}_{2} \mathrm{O}_{5}+$ $120 \mathrm{Kg} \mathrm{K}_{2} \mathrm{O} / \mathrm{ha}$. These results are in agreement with the findings of Rauf et al., (1998) and Ristow et al., (2008).

The yield of fruits per plant was produced highest of $208.88 \mathrm{gm}$ under treatment $\mathrm{F}_{5}$ of $250 \mathrm{~kg} \mathrm{~N}+120 \mathrm{~kg} \mathrm{P}_{2} \mathrm{O}_{5}+120 \mathrm{Kg} \mathrm{K}_{2} \mathrm{O} / \mathrm{ha}$ (Table 1). It was found at par with $177.78 \mathrm{gm}$ fruit yield/plant under treatment $\mathrm{F}_{6}$ but significantly higher than all other treatments. However, each increasing level of fertilizers improved fruit yield with upto $F_{5}$ level beyond which reduction in yield started and became significant at highest level of $\mathrm{F}_{7}$ fertilizer i.e. $350 \mathrm{~kg} \mathrm{~N}+160 \mathrm{~kg} \mathrm{P}_{2} \mathrm{O}_{5}+160 \mathrm{Kg}$ $\mathrm{K}_{2} \mathrm{O} /$ ha. It shows that higher dose of fertilizers beyond optimum dose, proved detrimental for crop. The increasing fertilizers level of $F_{1}, F_{2}, F_{3}, F_{4}$ and $F_{5}$ increased fruit yield/plant over $\mathrm{F}_{0}$ control by the margins of 27.04, 32.52, 69.64, 71.27 and 137.63 gm/plant or $28.0,45.6,97.7,100.0$ and $193.2 \%$, respectively. The fertilizer levels $\mathrm{F}_{6}$ and $\mathrm{F}_{7}$ reduced yield by 31.10 and 73.39 gm/plant or by 14.9 and $35.1 \%$, respectively as compared to the highest yield recorded with $\mathrm{F}_{5}$ fertilizers level. Fruit yield under different treatments might be attributes in general and to number of fruits/plant and fruit weight in particular. These results corroborate with the findings of Ristow et al., (2008). 
Table.1 Effect of increasing levels of NPK fertilizers on growth, flowering, yield attributes, fruit yield and quality of strawberry

\begin{tabular}{|c|c|c|c|c|c|c|c|c|c|c|c|c|c|c|c|}
\hline \multirow[t]{2}{*}{ Treatments } & \multicolumn{3}{|c|}{ Plant growth } & \multicolumn{3}{|c|}{ Flowering (days) } & \multicolumn{4}{|c|}{ Yield attributes } & \multirow{2}{*}{$\begin{array}{l}\text { Yield } \\
\text { Fruit } \\
\text { yield } \\
\text { (g/plan } \\
\text { t) }\end{array}$} & \multicolumn{4}{|c|}{ Quality of fruits } \\
\hline & $\begin{array}{l}\text { Plant } \\
\text { height } \\
(\mathrm{cm})\end{array}$ & $\begin{array}{l}\text { No. of } \\
\text { leaves } \\
\text { per } \\
\text { plant }\end{array}$ & $\begin{array}{l}\text { No. of } \\
\text { runners } \\
\text { per plant }\end{array}$ & $\begin{array}{l}\text { Flower } \\
\text { initiati } \\
\text { on }\end{array}$ & $\begin{array}{l}\text { Flower } \\
\text { ing } \\
\text { duratio } \\
\mathrm{n}\end{array}$ & $\begin{array}{l}\text { No. of } \\
\text { flower } \\
\text { s per } \\
\text { plant }\end{array}$ & $\begin{array}{l}\text { No. } \\
\text { of } \\
\text { fruits } \\
\text { per } \\
\text { plant }\end{array}$ & $\begin{array}{l}\text { Fruit } \\
\text { lengt } \\
\mathrm{h} \\
(\mathrm{cm})\end{array}$ & $\begin{array}{l}\text { Fruit } \\
\text { diam } \\
\text { eter } \\
(\mathrm{cm})\end{array}$ & $\begin{array}{l}\text { Fruit } \\
\text { weig } \\
\text { ht }(g)\end{array}$ & & $\begin{array}{l}\text { TSS } \\
(\%)\end{array}$ & $\begin{array}{l}\text { Acid } \\
\text { ity } \\
(\%)\end{array}$ & $\begin{array}{l}\text { Total } \\
\text { sugar } \\
\text { conte } \\
\text { nt } \\
(\%)\end{array}$ & $\begin{array}{l}\text { Vitam } \\
\text { in ' } \mathrm{C} \text { ' } \\
(\mathrm{mg} / \mathrm{g} \\
\text { ) }\end{array}$ \\
\hline $\begin{array}{l}\mathrm{F}_{0^{-}} \text {Control (No } \\
\text { fertilizer) }\end{array}$ & 7.98 & 8.90 & 1.53 & 42.73 & 30.73 & 14.50 & 7.13 & 2.71 & 2.05 & 10.00 & 71.25 & 7.03 & 0.85 & 4.86 & 49.75 \\
\hline $\begin{array}{l}\mathrm{F}_{1}-50 \mathrm{kgN}+30 \mathrm{Kg} \\
\mathrm{P}+30 \mathrm{Kg} \mathrm{K}\end{array}$ & 8.35 & 11.46 & 1.46 & 43.33 & 33.60 & 13.80 & 8.73 & 3.05 & 2.40 & 11.40 & 98.29 & 7.37 & 0.83 & 4.93 & 50.18 \\
\hline $\begin{array}{l}\mathrm{F}_{2}-100 \mathrm{kgN}+60 \mathrm{Kg} \\
\mathrm{P}+60 \mathrm{Kg} \mathrm{K}\end{array}$ & 9.12 & 11.36 & 1.80 & 45.20 & 33.60 & 15.93 & 8.46 & 3.27 & 2.28 & 12.20 & 103.77 & 7.68 & 0.80 & 5.12 & 51.17 \\
\hline $\begin{array}{l}\mathrm{F}_{3}-150 \mathrm{kgN}+80 \mathrm{Kg} \\
\mathrm{P}+80 \mathrm{Kg} \mathrm{K}\end{array}$ & 10.54 & 12.51 & 2.13 & 47.60 & 40.40 & 17.06 & 10.60 & 3.39 & 2.65 & 13.35 & 140.89 & 8.25 & 0.78 & 5.14 & 51.80 \\
\hline $\begin{array}{l}\mathrm{F}_{4}- \\
200 \mathrm{kgN}+100 \mathrm{Kg} \\
\mathrm{P}+100 \mathrm{Kg} \mathrm{K}\end{array}$ & 11.73 & 12.32 & 2.13 & 49.06 & 41.93 & 16.20 & 10.80 & 3.72 & 2.43 & 13.86 & 142.52 & 9.23 & 0.76 & 5.56 & 52.67 \\
\hline $\begin{array}{l}\mathrm{F}_{5}- \\
250 \mathrm{kgN}+120 \mathrm{Kg} \\
\mathrm{P}+120 \mathrm{Kg} \mathrm{K}\end{array}$ & 12.23 & 13.95 & 2.53 & 51.80 & 50.56 & 18.66 & 13.93 & 4.02 & 2.92 & 15.00 & 208.88 & 10.41 & 0.70 & 5.93 & 54.20 \\
\hline $\begin{array}{l}\mathrm{F}_{6}- \\
300 \mathrm{kgN}+140 \mathrm{Kg} \\
\mathrm{P}+140 \mathrm{Kg} \mathrm{K}\end{array}$ & 13.96 & 15.47 & 2.80 & 55.86 & 50.60 & 16.93 & 13.00 & 3.98 & 2.68 & 13.46 & 177.78 & 10.16 & 0.74 & 5.74 & 53.49 \\
\hline $\begin{array}{l}\mathrm{F}_{7}- \\
350 \mathrm{kgN}+160 \mathrm{Kg} \\
\mathrm{P}+160 \mathrm{Kg} \mathrm{K}\end{array}$ & 16.06 & 16.32 & 3.20 & 57.86 & 45.50 & 14.33 & 10.40 & 3.78 & 2.35 & 13.00 & 135.49 & 9.64 & 0.76 & 5.63 & 52.68 \\
\hline S.Ed. \pm & 0.87 & 0.79 & 0.24 & 1.71 & 1.54 & 1.22 & 1.51 & 0.14 & 0.15 & 0.65 & 18.19 & 0.23 & 0.02 & 0.18 & 0.38 \\
\hline C.D. $(\mathrm{P}=0.05)$ & 1.86 & 1.69 & 0.50 & 3.68 & 3.29 & 2.66 & 3.24 & 0.30 & 0.32 & 1.39 & 39.02 & 0.49 & 0.04 & 0.39 & 0.81 \\
\hline
\end{tabular}




\section{Effect on fruit quality}

The quality parameters of fruit viz., TSS, total sugar content and vitamin ' $\mathrm{C}$ ' content increased with increasing fertilizer levels significantly up to $\mathrm{F}_{5}$ level of $250 \mathrm{~kg} \mathrm{~N}+120$ $\mathrm{kg} \mathrm{P}_{2} \mathrm{O}_{5}+120 \mathrm{Kg} \mathrm{K} \mathrm{K}_{2} \mathrm{O} / \mathrm{ha}$ and beyond it fruit quality declined at higher fertility levels (Table 1). As regards the acidity content in fruits, least acidic fruits of $0.70 \%$ acidity were noted under treatment $\mathrm{F}_{5}$ against most acidic fruits of $0.85 \%$ acidity in control treatment $\mathrm{F}_{0}$. TSS content in strawberry fruits improved due to rapid mobilization of sugar and formation of more photosynthates and their translocation to the fruits which ultimately improved the source-sink relationship reflecting in higher TSS and total sugar content.

The acids under the influence of increasing NPK doses up to optimum might have converted into sugar due to which fruit acidity reduced with increasing NPK application. These results are in accordance with the findings of Gutal et al., (2005).
The results of present investigation have a clear indication that the application of $250 \mathrm{~kg}$ $\mathrm{N}+120 \mathrm{~kg} \mathrm{P}_{2} \mathrm{O}_{5}+120 \mathrm{Kg} \mathrm{K}_{2} \mathrm{O} / \mathrm{ha}$ proved to be the optimum dose of NPK fertilizers for higher yield and quality of strawberry fruits under central Uttar Pradesh condition.

\section{References}

Gutal, G. B., Barai, V. N., Mane, T. A., Purkar, J. K., Bote, N. L. 2005. Scheduling of nitrogen through drip method of irrigation for strawberry. Journal of Maharashtra Agricultural Universities. 30(2): 215-216.

Rauf, M. A., Mohammad Zubair, Jehangir Khan, Zafar Ali 1998. Effect of different levels of N.P.K. on the yield and growth of strawberry cv. 'Gorella'. Sarhad Journal of Agriculture, 14(1): 27-28.

Ristow, N.C., Carpenedo, S., Trevisan, R., Antuness, L.E.C., Freire, C.J. Das 2008. Response of different levels of NPK on strawberry production. Acta Horticultuae, pp. 287-290.

\section{How to cite this article:}

Jayant Kumar Maurya, Jagendra Pratap Singh, Saurabh Tomar and Rajeev Kumar. 2017. Optimization of NPK Fertilizers for Higher Yield and Quality of Strawberry (Gragaria $x$ Ananassa Duch.) Fruits. Int.J.Curr.Microbiol.App.Sci. 6(9): 1534-1538. doi: https://doi.org/10.20546/ijcmas.2017.609.188 